

NLINLS: a Differential Evolution based nonlinear least squares Fortran 77 program

\author{
Mishra, SK \\ North-Eastern Hill University, Shillong (India)
}

25 August 2007

Online at https://mpra.ub.uni-muenchen.de/4949/

MPRA Paper No. 4949, posted 18 Sep 2007 UTC 


\title{
NLINLS: A Differential Evolution based Nonlinear Least Squares Fortran 77 Program
}

\author{
SK Mishra \\ Dept. of Economics \\ NEHU, Shillong
}

Introduction: Curve fitting or estimation by nonlinear least squares is a difficult task. There are two types of algorithm that are often used for this purpose: those that need evaluation of derivatives and the others that do not. In the first category we have GaussNewton, Levenberg-Marquardt and Fletcher-Powell, Fletcher-Reeves, Rosen, QuasiNewton, etc while in the second category we have Powell, Rosenbrock, Hooke-Jeeves, Nelder-Mead and Box, etc (see Kuester and Mize, 1973). All of them are very prone to be caught into local minimum trap. Recently, some methods of global optimization have been developed that are based on some sort of stochastic process. The method of Differential Evolution (Storn and Price, 1995) is perhaps the most promising among them. In developing this program we have used DE as an optimizer of the nonlinear least square function. The DE is an evolutionary, population-based, algorithm; a development on the Genetic Algorithm. The DE as a method of optimization has been well tested on many extremely difficult multi-modal problems of nonlinear optimization (see at http://www1.webng.com/economics or http://www.freewebs.com/nehu_economics for its applications including estimation of Sato's nested CES production function (Mishra, 2006), Zellner-Revankar production function (Mishra, 2007-a) and joint production functions (Mishra, 2007-b), etc).

Fortran Compiler, NLINLS and User's Data: The program is written in Fortran 77 (http://www1.webng.com/economics or http://www.freewebs.com/nehu_economics for nlinls.txt version to directly copy-paste in a Fortran editor). To run the program one has to use a Fortran 77 compiler. FORCE-2.0 is a powerful compiler that may be downloaded from http://www.guilherme.tk/ (there going to Downloads and clicking on UK against Force208.exe) free and installed on the user's computer. Any other Fortran compiler may also be used.

\begin{tabular}{ccccr} 
HI & $\mathrm{X}_{1}$ & $\mathrm{X}_{2}$ & $\mathrm{X}_{3}$ & \multicolumn{1}{c}{$Y$} \\
No. & 470 & 300 & 10 & 8.55 \\
1 & 470 & 80 & 10 & 3.79 \\
2 & 285 & 300 & 120 & 4.82 \\
3 & 470 & 80 & 120 & 0.02 \\
4 & 470 & 80 \\
5 & 470 & 80 & 10 & 2.75 \\
6 & 100 & 190 & 10 & 14.39 \\
7 & 100 & 80 & 65 & 2.54 \\
8 & 470 & 190 & 65 & 4.35 \\
9 & 100 & 300 & 54 & 13.00 \\
10 & 100 & 300 & 120 & 8.50 \\
11 & 100 & 80 & 120 & 0.05 \\
12 & 285 & 300 & 10 & 11.32 \\
13 & 285 & 190 & 120 & 3.13
\end{tabular}

Then the program NLINLS may be copy-pasted from the source file (that may be in the text file such as NLINLS.txt) to the FORCE editor and saved as NLINLS.f. However, if you have obtained this program as NLINLS.f then after installing the Fortran compiler you may directly double click it. It will be taken up by FORCE automatically.

The first step in using the program is to make a text file (for example, HOUGEN.TXT in which data, note - only data, the colored portion - are to be stored in the scheme exemplified in the left panel). The sequence of columns is sl no., $\mathrm{x}_{1}, \mathrm{x}_{2}, \ldots, \mathrm{y}$. 
Please note that the data file and the NLINLS.f should be saved in the same folder (directory) to avoid typing long paths afterwards. However, this is only a suggestion.

The user of NLINLS program has to specify the parameters, bounds (limits) on them as well as the function to be fitted to data. This is done in the last subroutine of the program: REGFUNC. It has been specifically mentioned in the REGFUNC as to what is to be modified in the program and what is not be altered. Only three sets of changes are needed: (1) defining the set of parameters; $\mathrm{p} 1=\mathrm{p}(1), \mathrm{p} 2=\mathrm{p}(2)$, etc depending on the problem; (2) defining the set of variables, $\mathrm{x} 1=\operatorname{datum}(\mathrm{i}, 1), \mathrm{x} 2=\operatorname{datum}(\mathrm{i}, 2), \ldots, \mathrm{y}=$ datum(i, last), for example, in the Hougen problem x1 = datum(i, 1), x2 = datum(i, 2), x3 $=\operatorname{datum}(\mathrm{i}, 3), \mathrm{y}=\operatorname{datum}(\mathrm{i}, 4)$; and finally, (3) defining $\mathrm{yx}$ in terms of $\mathrm{p}$ and $\mathrm{x}$, such that in the Hougen problem the function is defined as $y x=(\mathrm{p} 1 * \mathrm{x} 2-\mathrm{x} 3 / \mathrm{p} 5) /(1 . \mathrm{d} 0+\mathrm{p} 2 * \mathrm{x} 1+$ p3 $* x 2+$ p4 *x3). Almost never one would require changing FORMAT(I5, 2F25.12), but one may change it if (at all) needed.

Once the changes in the program are made, it may be saved and compiled or even run directly. If no error has been committed in changing/redefining as advised above, the program will run. While it runs, the program asks for several inputs from the user. The program issues clear instructions to be (normally) followed.

1. "If help is needed ...." : The user (who has read this help document) will not possibly gain anything by feeding a non-zero number. So he/she should type 0 and strike the Enter key.

2. "Feed the name of input file ...": As has been advised above, the user is ready with the input data file, for example, in mydata.txt named file. He/she may type it and strike the Enter key.

3. "Number of observations and variables ...": The user should type the number of variables (e.g. 13 in the Hougen problem above) and the number of variables (including y) in the problem (e.g. 4 in the Hougen problem above). Then strike the Enter key. His/her input from the keyboard will be 13, 4 Enter.

4. "No. of parameters to be estimated": It is the number $\mathrm{m}$ in $\mathrm{p} 1, \mathrm{p} 2, \ldots$, Pm. For the Hougen problem it is 5. Input 5 and Enter.

5. "Would you specify any limits ... ": If the user has to specify some bounds (limits) on the values of parameter, he/she should type an integer number other than zero (0), e.g. 2, 3 or 4, etc and Enter. But if he/she has not to specify any bounds, he/she should type 0 and Enter.

6. If the user has chosen to provide bounds on the parameter, then he/she will be asked to provide those (lower and upper limits).

7. Specify the [lower upper, lower upper ..." : The user may specify them. For example, the lower upper bound on the parameters of the Hougen problem above may be given as

$$
-1010, \quad-1010, \quad-1010, \quad-1010, \quad-1010 \text { Enter }
$$

8. "Option: Would you minimize ..." : If the user wants to minimize sum of squares, he/she should type 0 and Enter. If he/she wants to maximize $\mathrm{R}^{2}$ then 
type any non-zero integer and strike the Enter key. Both amount to the same, but display different results.

Once these inputs are accepted by the computer, the program enters into DE optimization. The DE algorithm needs a number of inputs. These are:

1. "Population size and number of iterations ...": Population size should not be less than ten times the number of parameters to be estimated. For example, in the Hougen problem above, 5 parameters are there. So population size should not be less than 50. Unless the number of parameters is more than 10, population size $=$ 100 is good enough. In the main program the parameter IPRES may be 0 or 1 . If IPRES $=0$ then population size should be at least 10 times $M$ (no. of parameters) else it should be 20 times $M$ or more. Number of Iterations $=10000$ is enough for moderately sized problems.

2. "Cross-over probability ... and two scale parameters" : It depends on the complexity of the problem. If the problem appears to be simple, $(0.9,0.5,0)$ is alright and very effective. In some cases $(0.9,0.90 .01)$ performs better. In some other cases $(0.5,0.9,0.1)$ has worked. In case of complicated problems one may run the program several times with these alternatives $0.9,0.5,0$ Enter.

3. "Accuracy for convergence" : For most problems 0.0001 would be all right.

4. "Random number seed." : any 4-digit odd integer such as 5781 Enter.

5. "Name of output file" : Such as myresults.txt Enter.

And the program goes in for computation. All intermediate results pop up on the screen. All intermediate and final results including expected values of y are stored in the output file specified by the user (e.g. myresults.txt). Note that it is automatically saved in the same folder (directory) where NLINLS.f and data file are already saved. Then one may enter into that folder and double click the output file (e.g. myresults.txt) to view the results. One may also open it by any other text editor.

In case of any difficulty or further help, the user is most welcome to contact me at mishrsknehu@yahoo.com.

\section{References}

- Kuester, JL and Mize, JH (1973) Optimization Techniques with Fortran, McGraw-Hill Book Co., New York.

- Mishra, SK (2006) "A Note on Numerical Estimation of Sato's Two-Level CES Production Function”, SSRN at http://www.ssrn.com/author=353253

- Mishra, SK (2007-a) "Estimation of Zellner-Revankar Production Function Revisited." Economics Bulletin, 3 (14), pp. 1-7.

- Mishra, SK (2007-b) "Least Squares Estimation of Joint Production Functions by the Differential Evolution method of Global Optimization" Social Science Research Network (SSRN) at http://www.ssrn.com/author=353253

- Storn, R and Price, K (1995) "Differential Evolution - A Simple and Efficient Adaptive Scheme for Global Optimization over Continuous Spaces": Technical Report, International Computer Science Institute, Berkley. 
PROGRAM NLINLS

PARAMETER (MAXN=1000, MAXM=50) ! MAX NUMBER OF OBSERVATIONS $=1000$ AND MAX NUMBER OF INDEPENDENT VARIABLES $=50$. THIS MAY BE INCREASED OR DECREADED IF NEEDED. USUALLY ONE DOES NOT NEED CHANGING THEM.

THE LEAST SQUARES OBJECTIVE FUNCTION IN THIS PROGRAM IS OPTIMIZED BY THE "DIFFERENTIAL EVOLUTION ALGORITHM" OF GLOBAL OPTIMIZATION THIS METHOD WAS PROPOSED BY R. STORN AND K. PRICE IN 1995. REF -"DIFFERENTIAL EVOLUTION - A SIMPLE AND EFFICIENT ADAPTIVE SCHEME FOR GLOBAL OPTIMIZATION OVER CONTINUOUS SPACES" : TECHNICAL REPORT INTERNATIONAL COMPUTER SCIENCE INSTITUTE, BERKLEY, 1995.

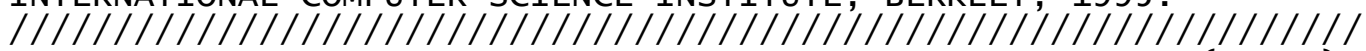
PROGRAM BY SK MISHRA, DEPT. OF ECONOMICS, NEHU, SHILLONG (INDIA)

PARAMETER $($ NMAX $=500$, MMAX $=50)$ ! MAXIMUM DIMENSION PARAMETERS FOR DE PARAMETER (IPRES $=1$ )! THIS SPECIFICATION IS FOR DIFFICULT FUNCTIONS PARAMETER (IPRES $=0$ )! THIS SPECIFICATION IS FORE GENERAL FUNCTIONS PARAMETER (IPRINT=500) ! FOR WATCHING INTERMEDIATE RESULTS

C IT PRINTS THE INTERMEDIATE RESULTS AFTER EACH IPRINT ITERATION. IMPLICIT DOUBLE PRECISION (A-H, O-Z) ! TYPE DECLARATION COMMON /RNDM/IU, IV ! RANDOM NUMBER GENERATION (IU = 4-DIGIT SEED) COMMON /REGDAT/DATUM (MAXN, MAXM), PARLIM, NDP, NDV , MINOPT, NLIMITS, FOUT NDP $=$ NO. OF DATA POINTS, NDV $=$ NO. OF VARIABLES (INCLUDING $Y$ )

C FOUT IS THE NAME OF OUTPUT FILE TO STORE FINAL RESULTS COMMON/KFF/KF, NFCALL, FTIT ! FUNCTION CODE, NO. OF CALLS, TITLE CHARACTER *80 FTIT ! TITLE: NONLINEAR LEAST SQUARES PROBLEM CHARACTER *80 FOUT ! THE OUTPUT FILE NAME

THE PROGRAM REQUIRES INPUTS FROM THE USER ON THE FOLLOWING

(1) FTIT= TITLE; (2) NO. OF VARIABLES IN THE FUNCTION (M);

(3) $\mathrm{N}=$ POPULATION SIZE (SUGGESTED 10 TIMES OF NO. OF VARIABLES, $M$, FOR SMALLER PROBLEMS $N=100$ WORKS VERY WELL);

(4) PCROS = PROB. OF CROSS-OVER (SUGGESTED : ABOUT 0.85 TO .99);

(5) $\mathrm{FACT}=$ SCALE (SUGGESTED 0.5 TO .95 OR 1 , ETC);

(6) ITER = MAXIMUM NUMBER OF ITERATIONS PERMITTED (5000 OR MORE)

(7) RANDOM NUMBER SEED (4 DIGITS INTEGER)

DIMENSION PARLIM(MAXM, 2)! LOWER AND UPEER LIMITS OF PARAMETERS

DIMENSION X(NMAX, MMAX), Y (NMAX, MMAX), FV (NMAX), A (MMAX), IR (4)

C

HELP=99.D0

99 WRITE $(*, *)$ ' '

$\operatorname{WRITE}(*, *)$ '

WRITE $(*, *)$ ' '

WRITE $(*, *)$ '

WRITE $(*, *)$ '

WRITE $(*, *)$ '

WRITE $(*, *)$

NONLINEAR LEAST SQUARES PROGRAM'

WRITTEN BY PROF. SK MISHRA'

DEPT. OF ECONOMICS, NEHU, SHILLONG'

\&--

FTIT $=$ 'NONLINEAR REGRESSION PROBLEM'

---------- PROVISION OF HELP

IF (HELP.EQ.99.D0) THEN

WRITE $(*, *)$ 'IF ANY HELP IS NEEDED FEED 1 (ONE) OR ANY OTHER NUMBER' $\operatorname{READ}(*, *)$ HELP

ELSE

GO TO 999

ENDIF

IF(HELP.EQ . 1.D0) THEN

CALL HELPFILE()

STOP

ENDIF 
HELP $=0$. D0

NLINLS

C

$999 \mathrm{KF}=1$ ! THIS PROGRAM WILL SOLVE ONE PROBLEM AT A TIME

$\mathrm{NRD}=0$ ! NRD $=0$ DATA FROM INPUT FILE WILL BE READ

$\mathrm{NQ}=0$

C

CALL REGFUNC (A, F, M, NQ, NRD)

$\operatorname{WRITE}(*, *)$

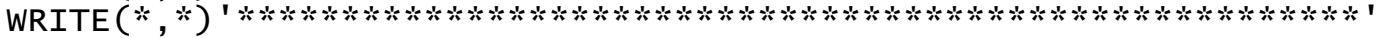

$\operatorname{WRITE}(*, *)$ ' '

WRITE $(*, *)$ 'NOW SPECIFY THE PARAMETERS OF DIFFERENTIAL EVOLUATION \&OPTIMIZATION'

WRITE $(*, *)$ 'PLEASE CONSIDER THE SUGGESTIONS, ALSO READ HELP FILE' WRITE $(*, *) '$

WRITE $(*, *)$ 'POPULATION SIZE [NPOP] AND NO. OF ITERATIONS [ITER] ?'

WRITE $(*, *)$ 'SUGGESTED : NPOP $=>100$ OR $=>10$ TIMES M (THE NUMBER OF

\& PARAMETERS) IF IPRES $=0$ ELSE 20 TIMES M;'

WRITE $(*, *)$ 'ITER 10000 OR LARGER'

READ $(*, *)$ NPOP, ITER ! POPULATION SIZE AND NO. OF ITERATIONS

$\mathrm{N}=$ NPOP'! RENAMED FOR CONVERIENCE

C

(PLEASE DO NOT CONFUSE IT TO BE AS NO. OF OBSERVATIONS IN DATA) $\operatorname{WRITE}(*, *)$

WRITE (**, *)'CROSSOVER PROBABILITY [PCROS], AND TWO SCALE PARAMETERS

\& [FACT AND FACT1] ?'

WRITE $(*, *)$ 'SUGGESTED: PCROS BETWEEN [0.5 - 0.9]; FACT BETWEEN [0.5 $\&-0.9]^{\prime}$

WRITE $(*, *)$ 'AND FACT1 BETWEEN $[0.0$ - 0.01] - LIMITS ARE INCLUSIVE'

READ $(*, *)$ PCYROS, FACT, FACT1

C EPS DETERMINES ACCURACY FOR TERMINATION. IF EPS $=0$, ALL ITERATIONS

C WOULD BE UNDERGONE EVEN IF NO IMPROVEMENT IN RESULTS IS THERE.

C ULTIMATELY "DID NOT CONVERGE" IS REOPORTED.

WRITE $(*, *)$ 'ACCURACY FOR CONVERGENCE - DEPENDS ON THE PROBLEM'

WRITE $(*, *) ' 0.0001$ IS OK; 0.0000001 IS OFTEN MORE THAN ENOUGH'

$\operatorname{READ}(*, *)$ EPS

WRITE $(*, *)$ '

WRITE $(*, *)$ 'RANDOM NUMBER SEED ?'

WRITE $(*, *)$ 'A 4-DIGIT POSITIVE ODD (NOTE, ODD) INTEGER [E.G. 5471]'

READ (*,*) IU !SEED OF RANDOM NUMBER (4-DIGIT ODD NATURAL NUMBER)

$\operatorname{WRITE}(*, *)$

WRITE $(*, *)$ 'NAME OF OUTPUT FILE IN WHICH RESULTS WILL BE STORED'

READ $(*, *)$ FOUT ! (IT IS THE THE GENERAL NAME OF THE OUTPUT FILE)

WRITE $(*, *) '$ '

OPEN(11, FILE=FOUT) ! OPENS THE OUTPUT FILE TO STORE RESULTS'

ICQ $=0$

NFCALL $=0$ ! INITIALIZE COUNTER FOR FUNCTION CALLS

GBEST=1.D30 ! TO BE USED FOR TERMINATION CRITERION

C

INITIALIZATION : GENERATE X(N,M) RANDOMLY

DO $I=1, N$

DO $\mathrm{J}=1, \mathrm{M}$

C

CALL RANDOM(RAND) ! GENERATES INITION X WITHIN

$X(I, J)=($ RAND $-0.5 D 0) * 2000$ ! GENERATES INITION $X$ WITHIN

$X(I, J)=($ RAND $-0.5 D 0) * 10$ ! GENERATES INITION $X$ WITHIN

C RANDOM NUMBERS BETWEEN -10 AND 10 (BOTH EXCLUSIVE)

ENDDO

ENDDO

$\operatorname{WRITE}(*, *)$ ' '

WRITE $(*, *)$ ' COMPUTING. PLEASE WAIT. LARGER PROBLEMS TAKE MORE TIME'

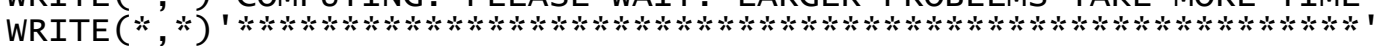

WRITE $(*, *)$ ' '

WRITE $(*, *)$ 'PROBLEM=' , KF, ' ' , FTIT 
$\operatorname{WRITE}(*, *)$ ' '

WRITE $(11, *) ' * * * * * * * * * * * * *$ INTERMEDIATE RESULTS $* * * * * * * * * * * * * * *$ '

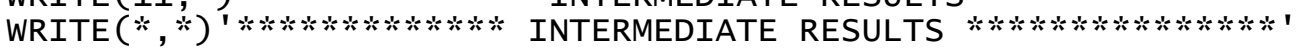
IPCOUNT $=0$

DO 100 ITR $=1$, ITER ! ITERATION BEGINS

CALL RANDOM(RAND)

RX1=RAND

CALL RANDOM(RAND)

RX2 $=$ RAND

C EVALUATE ALL X FOR THE GIVEN FUNCTION

DO $I=1, N$

DO $J=1, M$

$A(J)=X(I, J)$

ENDDO

CALL SETFUNC (A, M, F)

C STORE FUNCTION VALUES IN FV VECTOR $\mathrm{FV}(\mathrm{I})=\mathrm{F}$

ENDDO

C FIND THE FITTEST (BEST) INDIVIDUAL AT THIS ITERATION $\mathrm{FBEST}=\mathrm{FV}(1)$

$\mathrm{KB}=1$

$\mathrm{DO} I \mathrm{IB}=2, \mathrm{~N}$ IF(FV(IB) . LT. FBEST) THEN

$F B E S T=F V(I B)$

$K B=I B$

ENDDO

ENDIF

C BEST FITNESS VALUE = FBEST : INDIVIDUAL $\times(K B)$

C -

C GENERATE OFFSPRINGS

CALL RANDOM(RAND)

C

$\mathrm{NL}=\mathrm{N}$

IF (IPRES.GT.0) THEN

IF(RAND.GT.0.9D0) THEN

$\mathrm{NL}=\mathrm{N}$

ELSE

$N L=I N T(0.5 * N)$

ENDIF

C

ENDIF

$\mathrm{ICQ}=\mathrm{ICQ}+1$

IF(ICQ.GE . 50) ICQ $=0$

IF (ICQ.EQ. 0.AND.NL.LT.N) THEN

DO $\mathrm{IN}=\mathrm{NL}+1, \mathrm{~N}$

DO $\mathrm{J}=1, \mathrm{M}$

CALL RANDOM(RAND)

$X(I, J)=($ RAND $-0.5 D 0) * 10 . D 0$

ENDDO

ENDDO

ENDIF

C

DO I $=1, N$ ! I LOOP BEGINS

C INITIALIZE CHILDREN IDENTICAL TO PARENTS; THEY WILL CHANGE LATER DO $J=1, M$ $\mathrm{Y}(\mathrm{I}, \mathrm{J})=\mathrm{X}(\mathrm{I}, \mathrm{J})$ ENDDO 
C

CALL RANDOM(RAND)

$\mathrm{NL}=\mathrm{N}$

IF(IPRES.GT.0) THEN

IF(RAND.GT.0.10D0) THEN

$\mathrm{NL}=\mathrm{N}$

ELSE

$\mathrm{NL}=\mathrm{INT}(0.5 \% \mathrm{~N})$

ENDIF

C ENDIF

IF(IRI.LT.4) THEN

IRJ=INT (RAND*NL) +1

ELSE

IF (NL.LT.N) THEN

$I R J=I N T(R A N D *(N-N L))+N L$

ELSE

IRJ $=$ INT $(R A N D * N L)+1$

ENDIF

ENDIF

C CHECK THAT THESE THREE INDIVIDUALS ARE DISTICT AND OTHER THAN I IF(IRI.EQ.1.AND.IRJ.NE.I) THEN

$\operatorname{IR}(I R I)=I R J$

ENDIF

IF(IRI.EQ. 2.AND.IRJ .NE.I.AND.IRJ.NE.IR(1)) THEN

$\operatorname{IR}(I R I)=I R J$

ENDIF

IF(IRI.EQ.3.AND.IRJ.NE.I.AND.IRJ.NE.IR(1).AND.IRJ.NE.IR(2)) THEN $\operatorname{IR}(I R I)=$ IRJ ENDIF

IF (IRI . EQ . 4 . AND . IRJ . NE . I . AND . IRJ . NE . IR (1) . AND . IRJ . NE . IR (2) . AND .

* IRJ.NE.IR(3)) THEN

$\operatorname{IR}(I R I)=I R J$

ENDIF

ENDDO ! IRI LOOP ENDS

C CHECK IF ALL THE THREE IR ARE POSITIVE (INTEGERS)

DO IX=1, 4

$\operatorname{IF}(\operatorname{IR}(I X)$. LE.0) THEN

GOTO 20 ! IF NOT THEN REGENERATE

ENDIF

ENDDO

C THREE RANDOMLY CHOSEN INDIVIDUALS DIFFERENT FROM I AND DIFFERENT

C FROM EACH OTHER ARE IR(1), IR(2) AND IR(3)

C $====================$ RANDOMIZATION OF NCROSS

C RANDOMIZES NCROSS

NCROSS $=0$

CALL RANDOM(RAND)

IF(RAND . GT . RX1 . AND . RAND . LT . RX2) NCROSS $=1$

! IF RX1=>1, SCHEME 2 NEVER IMPLEMENTED

IF(RAND . GT . RX1 . AND . RAND . GT . RX2) NCROSS $=2$

! IF RX2 $=>1$, SCHEME 3 NEVER IMPLEMENTED

C

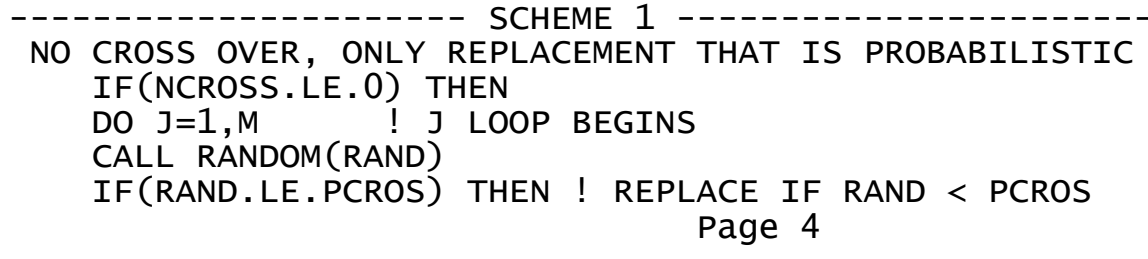


NLINLS

(J) $=X(\operatorname{IR}(1), \mathrm{J})+(X(\operatorname{IR}(2), \mathrm{J})-X(\operatorname{IR}(3), \mathrm{J})) * \mathrm{FACT}+$

$*(X(\operatorname{IR}(3), \mathrm{J})-0.5 \mathrm{D} 0 * \mathrm{X}(\operatorname{IR}(4), \mathrm{J})-.5 \mathrm{D} 0 * \mathrm{X}(\operatorname{IR}(1), \mathrm{J})) * \mathrm{FACT} 1$ ! CANDIDATE CHILD ENDIF

ENDDO ! J LOOP ENDS

ENDIF

C
C
C
C

THE STANDARD CROSSOVER SCHEME

CROSSOVER SCHEME (EXPONENTIAL) SUGGESTED BY KENNETH PRICE IN HIS

PERSONAL LETTER TO THE AUTHOR (DATED SEPTEMBER 29, 2006)

IF(NCROSS.EQ.1) THEN

CALL RANDOM(RAND)

$1 \quad J R=I N T(R A N D * M)+1$

$\mathrm{J}=\mathrm{JR}$

$2 \quad A(J)=X(\operatorname{IR}(1), J)+F A C T *(X(\operatorname{IR}(2), J)-X(\operatorname{IR}(3), J))+$

$*(X(\operatorname{IR}(3), J)-0.5 \mathrm{D} 0 * X(\operatorname{IR}(4), J)-.5 \mathrm{D} 0 * X(\operatorname{IR}(1), \mathrm{J})) * \mathrm{FACT} 1$

$3 \quad \mathrm{~J}=\mathrm{J}+1$

$\operatorname{IF}(J . G T . M) \quad J=1$

4 IF(J.EQ.JR) GOTO 10

5 CALL RANDOM(RAND)

IF(PCROS.LE.RAND) GOTO 2

$6 \quad \mathrm{~A}(\mathrm{~J})=\mathrm{X}(\mathrm{I}, \mathrm{J})$

$7 \quad \mathrm{~J}=\mathrm{J}+1$

$\operatorname{IF}(J . G T . M) \quad J=1$

8 IF (J.EQ.JR) GOTO 10

9 GOTO 6

10 CONTINUE

ENDIF

C
C
C
C

ESPECIALLY SUITABLE TO NON-DECOMPOSABLE (NON-SEPERABLE) FUNCTIONS

CROSSOVER SCHEME (NEW) SUGGESTED BY KENNETH PRICE IN HIS

PERSONAL LETTER TO THE AUTHOR (DATED OCTOBER 18, 2006)

IF (NCROSS.GE . 2) THEN

CALL RANDOM(RAND)

IF(RAND. LE. PCROS) THEN

CALL NORMAL (RN)

C

DO $J=1, M$

$A(J)=X(I, J)+(X(\operatorname{IR}(1), J)+X(\operatorname{IR}(2), J)-2 * X(I, J)) *(R N-0.5 D 0) * 2$

$A(J)=X(I, J)+(X(I R(1), J)+X(I R(2), J)-2 * X(I, J)) * R N * F A C T 1+$

$*(X(\operatorname{IR}(3), J)-0.5 D 0 * X(\operatorname{IR}(4), J)-.5 D 0 * X(\operatorname{IR}(1), J)) * F A C T 1$ ENDDO

ELSE

DO $J=1, M$

$A(J)=X(I, J)+(X(\operatorname{IR}(1), J)-X(\operatorname{IR}(2), J))+$

$*(X(\operatorname{IR}(3), J)-0.5 D 0 * X(\operatorname{IR}(4), J)-.5 D 0 * X(\operatorname{IR}(1), J)) *$ FACT1! FACT ASSUMED TO BE 1 ENDDO

ENDIF ENDIF

C

CALL SETFUNC(A,M,F) ! EVALUATE THE OFFSPRING

IF(F.LT.FV(I)) THEN ! IF BETTER, REPLACE PARENTS BY THE CHILD

$\mathrm{FV}(\mathrm{I})=\mathrm{F}$

DO $J=1, M$

$Y(I, J)=A(J)$

ENDDO

ENDIF

ENDDO ! I LOOP ENDS

DO $\mathrm{I}=1, \mathrm{~N}$

DO $J=1, M$

C

$X(I, J)=Y(I, J)$ ! NEW GENERATION IS A MIX OF BETTER PARENTS AND

ENDDO

BETTER CHILDREN

ENDDO 
IPCOUNT $=$ IPCOUNT +1

NLINLS

IF(IPCOUNT.EQ.IPRINT) THEN

DO $J=1, M$

$A(J)=X(K B, J)$

ENDDO

WRITE $(*, *)$ 'ESTIMATED PARAMETERS UP TO NOW'

WRITE $(*, *)(X(K B, J), J=1, M)$

WRITE $(11, *)$ 'ESTIMATED PARAMETERS UP TO NOW'

$\operatorname{WRITE}(11, *)(X(K B, J), J=1, M)$

IF(MINOPT. EQ.0) THEN

WRITE $(*, 101)$ FBEST

WRITE $(11,101)$ FBEST

ELSE

WRITE $(*, 102) \quad$-FBEST

WRITE $(11,102)$-FBEST

ENDIF

WRITE $(*, *) '$

WRITE $(11, *)^{\prime}$

101

C

102 FORMAT (1X,' R_SQUARE UP TO NOW = ', F25.16)

WRITE $(*, *)$ 'TOTAL NUMBER OF FUNCTION CALLS $=$ ', NFCALL

IF (DABS (FBEST-GBEST) . LT.EPS) THEN

WRITE $(*, *)$ 'COMPUTATION OVER. RESULTS STORED IN THE FOLLOWING FILE' WRITE $(*, *)$ FOUT

C $\operatorname{WRITE}(*, *), 1$

$\operatorname{WRITE}(11, *) '$ '

WRITE $(11, *) ; * * * * * * * *$

WRITE $(11, *)$

WRITE $(11, *)$ ' '

$\mathrm{NQ}=1$

$\mathrm{NRD}=1$

C

CALL REGFUNC ( $A, F, M, N Q, N R D)$

CLOSE(11) ! CLOSES THE OUTPUT FILE

WRITE $(*, *)$ 'THANK YOU'

STOP

ELSE

GBEST $=$ FBEST

ENDIF

IPCOUNT $=0$

ENDIF

C

ENDDO ! ITERATION ENDS : GO FOR NEXT ITERATION, IF APPLICABLE

C

WRITE $(*, *)$ 'DID NOT CONVERGE. REDUCE EPS OR RAISE ITER OR DO BOTH'

WRITE $(*, *)$ 'INCREASE POPULATION SIZE, PCROS, OR SCALE FACTOR(FACT)' CLOSE(11) ! CLOSES THE OUTPUT FILE

C END

$\mathrm{C}$
$\mathrm{C}$
$\mathrm{C}$
$\mathrm{C}$
$\mathrm{C}$
$\mathrm{C}$
$\mathrm{C}$
$\mathrm{C}$
$\mathrm{C}$
$\mathrm{C}$
$\mathrm{C}$
$\mathrm{C}$

SUBROUTINE NORMAL $(R)$

PROGRAM TO GENERATE $N(0,1)$ FROM RECTANGULAR RANDOM NUMBERS

IT USES BOX-MULLER VARIATE TRANSFORMATION FOR THIS PURPOSE.

---- BOX-MULLER METHOD BY GEP BOX AND ME MULLER (1958) -.-.---.-

BOX, G. E. P. AND MULLER, M. E. "A NOTE ON THE GENERATION OF

RANDOM NORMAL DEVIATES." ANN. MATH. STAT. 29, 610-611, 1958.

IF U1 AND U2 ARE UNIFORMLY DISTRIBUTED RANDOM NUMBERS $(0,1)$,

THEN $\mathrm{X}=[(-2 * \mathrm{LN}(\mathrm{U} 1)) * * .5] *(\operatorname{COS}(2 * \mathrm{PI} * \mathrm{U} 2)$ IS $\mathrm{N}(0,1)$

ALSO, $\quad X=[(-2 *$ LN (U1) $) * * .5] *(S I N(2 * P I * U 2)$ IS $N(0,1)$

$\mathrm{PI}=4 * A R C T A N(1.0)=3.1415926535897932384626433832795$

$2 * P I=6.283185307179586476925286766559$

Page 6 
IMPLICIT DOUBLE PRECISION (A-H,O-Z)

NLINLS

C

COMMON /RNDM/IU, IV

CALL RANDOM(RAND) ! INVOKES RANDOM TO GENERATE UNIFORM RAND $[0,1]$

U1=RAND ! U1 IS UNIFORMLY DISTRIBUTED [0, 1]

CALL RANDOM(RAND) ! INVOKES RANDOM TO GENERATE UNIFORM RAND $[0,1]$

U2=RAND ! U1 IS UNIFORMLY DISTRIBUTED $[0,1]$

$\mathrm{R}=\mathrm{DSQRT}(-2 . \mathrm{D} 0 * \mathrm{DLOG}(\mathrm{U} 1))$

$\mathrm{R}=\mathrm{R} * \mathrm{DCOS}(\mathrm{U} 2 * 6.283185307179586476925286766559 \mathrm{D} 00)$

C $\quad \mathrm{R}=\mathrm{R} * \mathrm{DCOS}(\mathrm{U} 2 * 6.28318530718 \mathrm{D} 00)$

RETURN

END

C RANDOM NUMBER GENERATOR (UNIFORM BETWEEN 0 AND 1 - BOTH EXCLUSIVE) SUBROUTINE RANDOM(RAND)

DOUBLE PRECISION RAND

COMMON /RNDM/IU, IV

$\mathrm{IV}=\mathrm{IU} * 65539$

IF(IV.LT.0) THEN

$I V=I V+2147483647+1$

ENDIF

RAND $=I V$

IU $=I V$

RAND $=$ RAND $* 0.4656613 D-09$

RETURN

END

C

SUBROUTINE SETFUNC (A,M,F)

C SET THE FUNCTION FOR GLOBAL OPTIMIZATION PROGRAM

IMPLICIT DOUBLE PRECISION $(\mathrm{A}-\mathrm{H}, \mathrm{O}-\mathrm{Z})$

COMMON /RNDM/IU, IV

COMMON /KFF/KF, NFCALL, FTIT

CHARACTER *80 FTIT

DIMENSION A $(*)$

NFCALL=NFCALL+1 ! INCREMENT TO NUMBER OF FUNCTION CALLS

C KF IS THE CODE OF THE TEST FUNCTION

C

$\mathrm{NQ}=0$

$\mathrm{NRD}=1$

CALL REGFUNC(A, F, M, NQ, NRD)

RETURN

END

SUBROUTINE HELPFILE()

WRITE $(*, *)$ 'HERE IS SOME HELP INFORMATION FOR YOU !'

WRITE $(*, *)$ ' '

WRITE $(*, *)$ 'FIRST FEED YOUR DATA AS FOLLOWS IN SOME TEXT FILE, FOR

\& EXAMPLE HOUGEN.TXT'

WRITE $(*, *) '$ '

WRITE $(*, *)$ ' $1 \begin{array}{lllll}1 & 470.0 & 300.0 & 10.0 & 8.55^{\prime}\end{array}$

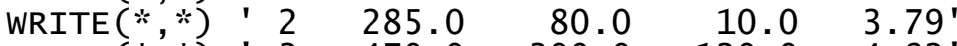

WRITE $(*, *)$ ' $3 \quad 470.0 \quad 300.0 \quad 120.0 \quad 4.82^{\prime}$

WRITE $(*, *)$ ' $4 \quad 470.0 \quad 80.0 \quad 120.0 \quad 0.02$ ',

$\operatorname{WRITE}(*, *)$ ' $\ldots \quad \ldots \ldots$

WRITE $(*, *), 13 \quad 285.0 \quad 190.0 \quad 120.0 \quad 3.13 '$

WRITE $(*, *)$ '

WRITE $(*, *)$ 'NOTE THAT SL NO. IS THE FIRST COLUMN AND Y IS THE LAST' WRITE $(*, *)$ 'THEN IN SUBROUTINE REGFUNC (THE LAST SUBROUTINE OF THIS \& PROGRAM

WRITE $(*, *)$ 'DEFINE PARAMETER NAMES (P1, P2, P3, ETC), AND VARIABLE $\&$ NAMES $(X 1, X 2, \ldots, Y) ;$

WRITE $(*, *)$ 'CHANGE THE FUNCTION (YX=AS PER YOUR SPECIFICATION), E.G. \& HOUGEN FUNCTION IS' 
NLINLS

WRITE $(*, *)$ ' SPECIFIED AS: YX $=(P 1 * X 2-X 3 / P 5) /(1 . D 0+P 2 * X 1+P 3 * X 2+P 4 * \times 3)$ ' WRITE $(*, *)$ 'MODIFY FORMAT SPECIFICATION (ALMOST NEVER NEEDED)'

WRITE $(*, *)$ 'SAVE THE PROGRAM AND RUN. FOLLOW THE INSTRUCTIONS. IF $\&$ YOU ARE DONE RUN THE PROGRAM AGAIN. THANK YOU'

RETURN

END

C

SUBROUTINE REGFUNC( $P, F, M, N Q, N R D)$

PARAMETER (MAXN $=1000, M A X M=50)$

C MAXN=MAX NUMBER OF OBSRVATIONS, MMAX = MAX NUMBER OF PARAMETERS

C MAXN=MAX NO. OF VARIABLES. UNLESS YOUR OBSERVATIONS EXCEED 1000 OR

C NUMBER OF EXPLANATORY VARIABLES EXCEED 50 DO NOT CHANGE IT.

IMPLICIT DOUBLE PRECISION (A-H, O-Z)

COMMON /REGDAT/DATUM (MAXN, MAXM) , PARLIM, NDP, NDV , MINOPT, NLIMITS, FOUT

CHARACTER *80 FIN, FOUT! NAME OF INPUT AND OUTPUT FILES

C NAME OF INPUT AND OUTPUT FILES MAXIMUM 80 CHARACTERS LONG

DIMENSION PARLIM(MAXM,2)! LOWER AND UPPER LIMITS OF PARAMETERS

DIMENSION $P(*)$ ! PARAMETERS

NOW READ DATA FROM THE FILE ONLY ONCE (IN THE BEGINNING)

IF(NRD.EQ.0) THEN

WRITE $(*, *)$ 'FEED THE NAME OF INPUT FILE IN WHICH DATA ARE STORED'

READ $(*, *)$ FIN ! (IT IS THE THE GENERAL NAME OF THE INPUT FILE)

WRITE $(*, *)$ ' '

WRITE $(*, *)$ 'NUMBER OF OBSERVATIONS AND VARIABLES (INCLUDING $Y$ ): $X 1$,

$\& X 2, \ldots, Y ?^{\prime}$

WRITE $(*, *)$ ' SUPPOSE $Y=F(X 1, X 2, X 3)$, THEN WE HAVE 4 VARIABLES IN ALL' READ $(*, *)$ NDP, NDV!NO. OF OBSERVATIONS AND VARIABLES INCLUDING $Y$

WRITE $(*, *)$ '

WRITE $(*, *)$ 'NO. OF PARAMETERS TO BE ESTIMATED ?'

$\operatorname{READ}(*, *) M$ ! (NO. OF PARAMETERS TO BE ESTIMATED)

$\operatorname{WRITE}(*, *)$

WRITE $(* ; *)$ ' WOULD YOU SPECIFY ANY LIMITS TO THE PARAMETERS ? IF NO

$\&$ THEN FEED 0 (ZERO) ELSE FEED A NONZERO INTEGER'

$\operatorname{READ}(*, *)$ NLIMITS

WRITE $(*, *)$ ' '

IF(NLIMITS. NE.0) THEN

WRITE $(*, *)$ 'SPECIFY THE [LOWER UPPER, LOWER UPPER, LOWER UPPER,...]

\& LIMITS OF PARAMETERS FROM THE FIRST TO THE LAST'

$\operatorname{READ}(*, *)(\operatorname{PARLIM}(\mathrm{J}, 1), \operatorname{PARLIM}(\mathrm{J}, 2), \mathrm{J}=1, \mathrm{M})$

$\operatorname{WRITE}(*, *)$ ' '

ENDIF

$\operatorname{OPEN}(7$, FILE=FIN) ! OPENS INPUT DATA FILE TO READ DATA (SL_NO., X, Y)

DO $I=1, N D P$

$\operatorname{READ}(7, *) \operatorname{NSL},(\operatorname{DATUM}(I, J), J=1, N D V)$ ! READS SL NUMBER, X AND Y

ENDDO

CLOSE(7) ! CLOSES THE INPUT FILE

IF (NSL. NE. NDP) WRITE $(*, *)$ 'MISMATCH IN NUMBER OF OBSERVATIONS'

WRITE $(*, *)$ 'OPTION: WOULD YOU MINIMIZE THE SUM OF SQUARED ERRORS

$\&($ FEED 0$)$ '

WRITE $(*, *)$ 'OR MAXIMIZE R_SQUARE (FEED ANY NON-ZERO INTEGER)'

$\operatorname{READ}(*, *)$
$\operatorname{WRITE}(*, *)$
$\operatorname{MRINOPT}$

$\mathrm{NRD}=1$ ! ONCE NRD $=1$ DATA FROM INPUT FILE WOULD NOT BE READ AGAIN ENDIF

C

$\mathrm{N}=$ NDP ! RENAMING THE PARAMETER JUST FOR CONVENIENCE

$S Y=0 . D 0$ ! INITIALIZE SUM OF $Y$

SSY $=0 . D 0$ ! INITIALIZE SUM OF SQUARED $Y$

SSE $=0 . D 0$ ! INITIALIZE SUM OF SQUARED ERRORS

C CHECKING THE LIMITS OF PARAMETERS AND BRINGING WITHIN LIMITS IF

C ANY OF THEM CROSS THE LIMITS - IT IS REQUIRED IN SOME CASES

Page 8 
IF(NLIMITS.NE.0) THEN

NLINLS

DO $J=1, M$

$\operatorname{IF}(P(J) \cdot L T \cdot \operatorname{PARLIM}(J, 1)$.OR. $P(J) \cdot G T \cdot \operatorname{PARLIM}(J, 2))$ THEN

CALL RANDOM(RAND)

$\operatorname{P}(\mathrm{J})=\operatorname{PARLIM}(\mathrm{J}, 1)+(\operatorname{PARLIM}(\mathrm{J}, 2)-\operatorname{PARLIM}(\mathrm{J}, 1)) * \operatorname{RAND}$

ENDIF

ENDDO

ENDIF

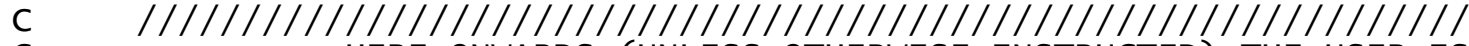

C - - - - HERE ONWARDS (UNLESS OTHERWISE INSTRUCTED) THE USER IS

C - -

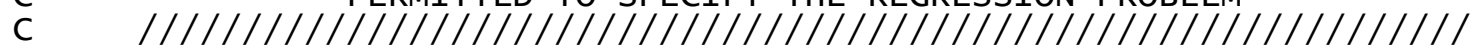

C PLEASE REDEFINE PARAMETERS $P 1=P(1), P 2=P(2), \ldots, P M=P(M)$

$\mathrm{P} 1=\mathrm{P}(1)$

$P 2=P(2)$

$P 3=P(3)$

$P 4=P(4)$

$\mathrm{P} 5=\mathrm{P}(5)$

C $\operatorname{REDEFINE~} \operatorname{VARIABLES} X 1=\operatorname{DATUM}(I, 1), X 2=\operatorname{DATUM}(I, 2), X 3=\operatorname{DATUM}(I, 3) \ldots$,

C FINALLY Y=DATUM(I, NDV). REMEMBER THAT $Y$ IS THE LAST COLUMN DATA

DO $I=1, N$

$\mathrm{X} 1=\operatorname{DATUM}(\mathrm{I}, 1)$

$\mathrm{X} 2=\operatorname{DATUM}(\mathrm{I}, 2)$

$X 3=\operatorname{DATUM}(I, 3)$

$\mathrm{Y}=\operatorname{DATUM}(\mathrm{I}, 4)$

C NOW DEFINE YOUR REGRESSION FUNCTION YX IN TERMS OF $X$ AND $P$

C YX IS THE EXPECTED VALUE OF $Y$ IN TERMS OF $X$ AND $P$. FOR EXAMPLE

C WE DEFINE THE HOUGEN FUNCTION AS GIVEN BELOW

$\mathrm{YX}=(\mathrm{P} 1 * \mathrm{X} 2-\mathrm{X} 3 / \mathrm{P} 5) /(1 . \mathrm{D} 0+\mathrm{P} 2 * \mathrm{X} 1+\mathrm{P} 3 * \mathrm{X} 2+\mathrm{P} 4 * \mathrm{X} 3)$ ! HOUGEN FUNCTION

1 FORMAT(I5, 2F25.12) ! THIS IS THE FORMAT OF OUTPUT. IF THE INTEGER PART OF Y DOES NOT EXCEED 11 DIGITS AND THE FRACTION PART DOES NOT EXCEED 12 DIGITS THEN THIS FORMAT NEED NOT BE CHANGED AT ALL.

C - -

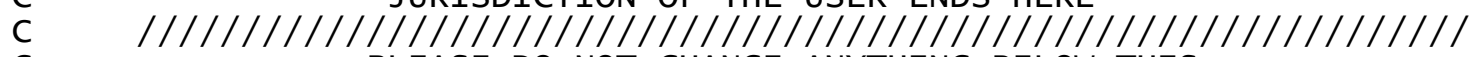

C - - - - - PLEASE DO NOT CHANGE ANYTHING BELOW THIS -

C $\quad / / / / / / / / / / / / / / / / / / / / / / / / / / / / / / / / / / / / / / / / / / / / / / / / / / / / / / / 1$

IF(NQ.NE.0) WRITE(11,1)I, Y, YX ! STORE IN OUTPUT

C WRITES SL NO. Y AND EXPECTED $Y$ (THAT IS YX) IN THE OUTPUT FILE $\mathrm{ER}=(\mathrm{Y}-\mathrm{YX})$ ! ESTIMATED ERROR

$S S E=S S E+E R * 2$ ! SUM UP THE SQUARED ERROR

$S Y=S Y+Y$ ! SUM OF $Y$

SSY $=S S Y+Y * 2$ ! SUM OF SQUARED $Y$

\section{ENDDO}

RMS2 $=S S E / N$ ! MEAN SQUARED ERROR (SQUARED 'ROOT MEAN SQUARE' OR RMS) $\mathrm{V}=\mathrm{SSY} / \mathrm{N}-(\mathrm{SY} / \mathrm{N}) * * 2$ ! VARIANCE OF $\mathrm{Y}$

$\mathrm{RSQ}=1 . \mathrm{D} 0-\mathrm{RMS} 2 \mathrm{~N}$

IF(MINOPT.EQ.0) THEN

$\mathrm{F}=\mathrm{SSE}$ ! THE MINIMAND FUNCTION IS THE SUM OF SQUARED ERRORS

ELSE

C

$\mathrm{F}=-$ RSQ ! MINIMAND FUNCTION IS THE NEGATIVE OF R_SQUARE

MINIMIZATION OF NEGATIVE OF R_SQUARE MAXIMIZES THE R_SQUARE

ENDIF

IF (NQ.NE.0) THEN

WRITE $(11, *)$ ' [THE ORDER OF ABOVE OUTPUT IS: SL NO., Y, EXPECTED Y]' $\operatorname{WRITE}(11, *)$ '

WRITE $(11, *)$ 'ESTIMATED PARAMETER ARE AS FOLLOWS' 
NLINLS

WRITE $(11, *)(P(J), J=1, M)$ ! THESE ARE M PARAMETERS

WRITE $(11, *)$ 'SUM OF SQUARED ERRORS = ', SSE

WRITE $(11, *)$ 'R-SQUARE = ', RSQ

$\operatorname{WRITE}(11, *)$ 'RMS = ', DSQRT(RMS2)

ENDIF

RETURN

END 